\title{
A Etnografia como ciência auxiliar do estudo da história do Direito
}

\author{
Fernando Henrique Mendes de Almeida \\ Docente livre de Direito Administrativo na Faculdade \\ de Direito da Universidade de São Paulo
}

\section{Introdução}

1. Em 1939, tivemos o ensejo de publicar um trabalho ${ }^{1}$ que nos havia sido suscitado pela intuição de que uma ciência nova se fazia necessária como instrumento de poderoso auxílio para a compreensão de não poucas relações jurídicas e leis antigas que as regularam. O trabalho, como ẻ forçoso reconhecer, é repentino e imperfeitíssimo e só o perdôa a circunstância de haver sido escrito à altura dos ridentes e saudosos 30 anos de idade, quando tínhamos convicção de nossa maturação e o leitor, desgraçadamente, não a tinha.

A ciência nova, de que falamos aqui, tomou impulso no século passado e se chama, numa expressão consagrada: Etnografia.

\section{II}

\section{O que é a Etnografia}

2. A ciência que se destina a estudar povos, como unidades ou grupos naturais, tomando por base suas ori-

1. É: O folclore nas Ordenações do Reino, constante do volume Lvi (1939), da Revista do Arquivo Municipal. 
gens comuns, seus costumes, sua língua e posição geográfica das terras em que vivem tem um nome, hoje. E seu nome é: Etnologia ${ }^{2}$. Como um conjunto de conhecimentos vastos, que é, tal ciência compreende um gênero, de que participam duas espécies, a saber:

$\left.1 .^{\circ}\right)$ a Etnogenia;

$\left.2 .^{\circ}\right)$ a Etnografia ${ }^{3}$.

A Etnogenia ocupa-se de estudar a origem dos povos; da parte descritiva da Etnologia, cujo objeto tivemos o ensejo de determinar, cuida a Etnografia.

Ora, os costumes dos povos aparecem: a) como expressão do meio de os identificar e distinguir; b) como manifestação de idéias do vulgo, sejam estas produtos de concepção mental primitiva, ou resíduo de elementos eruditos, de que se perdeu consciência, quanto à origem ${ }^{3 \cdot A}$. Pois bem. A parte da Etnografia que se desincumbe de estudar os fenômenos apontados na letra " $b$ " supra chama-se: "folk-lore" Este nome não foi criado com a ciência a que êle foi dado, como designação especial, pois, ela, como veremos, preexistiu a êle, sendo tratada como "demopsicologia", "tradições populares" ou "antiguidades vulgares".

3. Ao referir a importância da Etnografia como auxiliar da história do Direito em geral, não estamos propondo ao leitor qualquer idéia abstrusa, nem procurando ser original com a apresentação de mais uma novidade. Tal importância já foi pressentida por muitos escritores. Com ef eito, estudo do homem e da terra, bem como do trabalho de que aquêle vive (Tecnografia), dos usos que se trans-

2. Leite de VAsconceulos, Conceito de Etnologia, na Revista Lusitana vol. XVI, 1913, págs. 330 a 337.

3. Leite de VAsconcelos, ob. cit., lug. cit. e Opúsculos, Parte I do vol. V, págs. 2 a 8.

3A. No interior, muitos acreditam que, quando gritam em grutas e o eco se faz sentir, êste último é a voz de uma moça encantada. Este fato, que se prende à tradição das mouras encantadas em Portugal, está ligado à vida mítica da ninfa Eco (veja: BoumLeT: Dictionnaire Classique, vb. Eco). 
mitem de geração a geração, de superstições e parlendas, de pulhas ou pegas (Folklore); estudo de usos e modas, de pratos e adágios, que ou passam, para se transtormarem noutros, ou persistem, a Etnografia of erece a vantagem de podermos explicar muitos aspectos do Direito Antigo. É o que se percebe, inúmeras vêzes, quando se nos enseja ler textos das Ordenações Afonsinas, Manuelinas e Filipinas, bem como das disposições suplementares do Direito Canônico, conhecidas como Constituições de Bispados, assim em Portugal, como no Brasil. Onde, contudo, a valia e o prestadio da nova ciência transparecem é, sobretudo, na ocasião em que nos prendemos à leitura do livro $5 .^{\circ}$ das Ordenações Filipinas, no qual são cominadas terriveis penas a todos quantos fazem feitiço, ou a êste dão curso ou crédito.

4. As considerações ora feitas devem ser lidas e meditadas. Não podem suscitar dúvidas, pois, nada conłêm de especialmente inovador. Aliás, a propósito disto, ocorre-nos recordar uma passagem de nossa vida, de quando tivemos a fortuna de passar pelos bancos acadêmicos desta Faculdade. Foi em 1932. Para ministrar-nos ensinamentos de Direito Penal, foi designado o saudosíssimo professor Luís Barbosa da Gama Cerqueira, velho amigo de Joaquin Canuto de Figueiredo, nosso avô materno, desde que andou lá pelas bandas de São José do Além Paraíba e de Pôrto Novo do Cunha, nos idos do século passado.

O professor Gama Cerqueira, que era um espírito curioso, ao invés de ater-se à desencantadora redação do Código Penal de 1890, por êle passava ràpidamente, para ocupar-se com o título $3 .^{\circ}$ do livro $5 .^{\circ}$ das Ordenações Filipinas, no qual declarava, por intuição (porque não era conhecedor da Etnografia), havermos as raízes do fetichismo gêge-nagò da Bahía e do Rio de Janeiro. Como se tivesse ocupado longamente disso, recordamos que minoria da turma de seus alunos esboçou a idéia de protestar. Nela não nos incluímos. Primeiramente, porque não estava em nosso temperamento fulgir de valentão diante de um mestre, sobretudo 
de um mestre respeitabilíssimo; segundo, porque, precisamente, ao tempo de estudante, éramos encarregado de reger, como professor adjunto, a cadeira de História da Música, no Conservatório de São Paulo e, portanto, estávamos relativamente habilitados a atinar com a utilidade das observações, alvo de injusta e insólita censura. Escoados os dias, os meses e os anos, em 1934, começamos a ver sazonados os primeiros frutos das observações do professor Gama Cerqueira. Foi quando, às vésperas da conclusão do curso de bacharelado em ciências jurídicas e sociais, procuramos associar o nosso imaturíssimo conhecimento da Etnografia ao texto do livro $5 .^{\circ}$, tít. $3 .^{\circ}$, das Ordenações Filipinas, de onde se seguiu a publicação do trabalho acima referido ${ }^{3 \mathrm{~B}}$, do qual, tomando por base a frase de Melo FrEIRE acêrca das "Institutiones Iuris Civilis Lusitani", podemos dizer que é obra "repentina, imperfecta et intra paucos menses confecta" Mas, do tentâme se tirou um resultado: algumas informações que embasaram trabalhos posteriores de outros, dotados de mais ponderação e, sobretudo, de mais segurança para o exame das questões, à luz da Etnografia.

5. Por outro lado, se a ciência aqui referida, isto é, a Etnografia, não fôsse, porventura, instrumento de cultura, não se lhe dedicariam homens do porte de Melo Morais Filho, Sílvio Romero, Amadeu Amaral, João Ribeiro, Joaquim Ribeiro e Luís da Câmara Cascudo, para falar nos seus mais dedicados estudiosos no Brasil. Nem despertaria ela a curiosidade de humanistas do valor de Teófilo Braga, Alexandre Herculano, Adolfo Coelho e José Leite de Vasconcelos, em Portugal. Nem estaria, como num veeiro de ricas informações, sugerida, através de obras de ficção, nos escritos do Padre Manuel Bernardes, Dom Francisco Manuel de Melo, Camillo Castello Branco e Francisco Xavier de Oliveira, mais conhecido como Cavaleiro de Oliveira.

3B. Veja nota 1 de rodapé. 
A Etnografia, para a compreensão de textos antigos de nossas leis, é arma poderosíssima. É de se lamentar, por isto, que estudiosos de nossas instituições não lhe dêm a atenção que realmente merece.

\section{III}

\section{Área de estudo da Etnografia}

6. A Etnografia aplica-se tanto ao estudo dos povos cultos, quanto ao dos povos incultos, e, assim, às comunidades incultas existentes nos agrupamentos civilizados e a influência que logram ter nestes, pelo processo da sedimentação. Por isto é que há nela aquela importante parte que, tratando de "tradições populares", é chamada: folk-lore, isto é: folk (=povo), lore (=saber). E necessário, todavia, que, desde já, tenhamos cautela com o que, no Brasil, se tem indevidamente incluído no objeto do "folk-lore". Assim procedendo, perdemos a prevenção que nutrimos contra êle. A expressão "folk-lore", entre nós brasileiros, se desvirtuou devido, principalmente, à imprensa. Esta que, entre nós nada mais representa, com raras exceções, do que sub-cultura, ou melhor, "ignorância informada", é a principal fonte da desnaturação do sentido da expressão, o qual diz respeito a uma ciência, a um conjunto de conhecimentos tão respeitável quanto muitos outros que lograram obter o respeito e a consideração até dos homens medianos. A precaução, que é de urgência tomar, há de ser tomada através da explicação de como surgiu o têrmo e de qual foi, antes dêle, o modo de designar os conhecimentos que se encontram em seu estudo, em bases circunspectas. que iremos tentar fazer, ainda que não esperançados de testemunhar efeitos capazes de garantir, para a dita ciência, todo o respeito que ela merece e lá fora lhe é tributado. Para, em suma, pôr fim a possíveis incompreensões de leitores atarantados com o emprêgo arbitrário e abusivo da expressão em foco. 
7 A palavra "folk-lore" surgiu pela primeira vez no número de 22 de agôsto de 1896, do jornal londrino chamado "The Athenaeum". Empregou-a, sob o pseudônimo de Ambrose Merton, o arqueólogo inglês William JoHN Тномs, para substituir têrmo até então em uso para significar "Antiquitates Vulgares" ou "Popular Antiquities". Essas "Antiquitates Vulgares" eram aquêles costumes que, de geração a geração, se transferem e que êste ou aquêle povo conserva, sem ter, por vêzes, consciência de explicá-los e que, explicados, esclarecem muitas dúvidas ${ }^{4}$, inclusive aquelas que velhos textos de leis portuguêsas, essenciais ao estudo da história do Direito no Brasil, suscitam freqüentemente. De sorte que, a rigor, não há como repudiar a utilidade de tal soma de conhecimentos que raramente a curiosidade do jurista procura.

\section{IV}

\section{Aplicações de quanto se disse aqui}

8. Na "Acta" do $2 .^{\circ}$ Concílio de Braga proibe-se aos cristãos culto aos astros (Non liceat tenere traditiones gentilium, et observare vel colere elementa, aut lunae, aut stellarum cursum). $\mathrm{E}$ as Constituições de Bispados vieram a declarar:

"E proibimos sob pena de excomunhão maior que. pessoa. faça juízo ou levante figuras pelos movimentos, ou aspectos do sol, lua, ou estrelas.

4. Vejam-se: Cocchiara (Giuseppe), Folklore, ed. Hoeppli, Milão, 1927, págs. 1 e 2; RAmos (Arthur), Estudos de Folk-lore, págs. 11 e 12; Amaral (Amadeu), Os estudos folclóricos no Brasil, ed. Instituto Progresso Editorial S/A., págs. 2 a 38; LeIte DE VASCONCELOS, ob. cit., pág. 8 , nota 1 , pág. 10 , nota 1 , pág. 11, notas 1 e 2 e Revista Lusitana, XVI, 1913, págs. 330 a 337. 
E de uma constituição do Bispado da Guarda se repete, noutras palavras, a mesma vedação, para não falar na do Pôrto, datada de 1687, que comina castigos severos a quem "reze à lua" ou "às estrêlas" ${ }^{5}$. É a proibição de que se façam sortilégios a poder da astrologia. Ora, sabe-se quanta influência houve das Constituições de Bispados no livro $5 .^{\circ}$, título III, das Ordenações Filipinas. O estudante da História do Direito Nacional, que já deve saber de tal influência, pela Etnografia, compreenderá que a proibição de ligar os astros a fatos da vida humana (pôsto persista no povo e residualmente em pessoas cultas, ou como tais havidas) é antiga como a "Ora maritima" de Avieno, ou o que consta da Geografia de Strabão ${ }^{6}$.

9. Nalgumas legislações, as testemunhas dos testamentos deveriam ser 7. Era isto uma homenagem à significação simpática que o povo dava a tal número, o que dispensa maiores considerações ${ }^{7}$.

10. Do simples rifão "Bofetada! Mão cortada", se descobre a pena cruel de mutilação da mão, da qual, aliás, nos dão notícia, ainda, muitas das passagens das Ordenações ${ }^{8}$.

11 Relativamente ao culto das águas, muitas são as passagens que se encontram assim nas Ordenações como nas Constituições dos Bispados. São as recomendações de que não se veja em água, cristal ou espêlho, nem que ben-

5. Leite de Vasconcelos, Tradições Populares de Portugal, págs. 2 e 3 .

6. LeITE DE VAsconcelos, Tradições Populares de Portugal págs. 1 e 2.

7. Sôbre êste assunto, veja-se: LeITE dE VAsconcelos, Número 13, nos Opúsculos, vol. VII Etnologia, parte II, pág. 1.343.

8. Veja-se: Leite DE VAsconcelos, Mão cortada, nos Opúsculos, VII, Parte II, pág. 1.323. - Para texto legal, veja-se: Ordenação Filipina do livro $5 .^{\circ}$ título 138. 
zam "espada que passou o Douro e o Minho por três vêzes". É matéria realmente encontradiça nos textos ${ }^{9}$.

12. A fitolatria é até hoje frequente entre o vulgo. Por isto o roubo de pedra de altar era rigorosamente punido ${ }^{10} \mathrm{e}$ as Constituições do Bispado de Lamêgo, do ano de 1563 , proibiam procissões a outeiros e a penedos ${ }^{11}$, tradição que está viva no topônimo Montessanto ${ }^{12}$.

Por cima do rio Douro há um penedo chamado MeioDia, o qual, segundo crença popular, tem três minas de ouro, prata e peste ${ }^{13}$, bem como Mouras Encantadas. E isto é mais um atestado da fitolatria proibida nas Ordenações Filipinas do livro $5 .^{\circ}$, título $3^{\circ}$. Contudo, as Senhoras da Penha e da Lapa são admitidas no culto católico. Ademais, quem ignora as muitas superstições, ligadas ao casamento, e associadas às pedras ${ }^{14}$ ?

13. Inumeráveis são os exemplos em que a Etnografia oferece ao estudioso da História do Direito Nacional elementos de compreensão de textos antigos. Aqui fizemos apenas uma ligeira excursão por assunto de tamanho interêsse, precisamente na esperança de que pessoas de mais largueza de vistas e de mais rica bibliografia aceitem, de uma vêz por tôdas, a afirmação que nos preocupou neste artigo.

9. Leite DE VAsconcelos, Tradições Populares de Portugal, págs. 66 a 68; As águas, Nota acêrca das fontes, Superstições de rios nos Opúsculos, V, Parte I, págs. 516 a 521. Para textos legais, veja-se a Ordenação Filipina do livro $5 .^{\circ}$, tít. $3 .^{\circ}$, ítem 3 , acêrca da Rabdomancia, da Hidromancia, da Cristalomancia e da Catoptromancia. Consulte-se: Silva Pereira, Repertório das Ordenações $I$, nota da pág. 51.

10. ORDenação Filipina, do livro $5 .^{\circ}$, tít. III, in principi.

11. Leite de Vasconcelos, Tradições Populares de Portugal, pág. 85

12. Leite de Vasconcelos, Tradições Populares de Portugal pág. 85.

13. Leite DE VAsconcelos, $O$ penedo do Meio-Dia VII, Parte II pág. 1.321 dos Opúsculos. E no mesmo autor, Tradicões Populares de Portugal, págs. 89/90.

14. Cf. Té́filo Braga, Origens Poéticas do Cristianismo págs. 134 e 135 . 
14. Ocorre-nos, também, lembrar, aqui, as doutíssimas lições do professor João Braz de Oliveira Arruda. De copioso saber e dedicada preocupação em transmiti-lo, foi êle um dos mestres desta Faculdade, dentre os a quem devemos nossa formação, preocupados, ainda com as idéias da Etnografia como auxiliar da compreensão da História do Direito Nacional. Fê-lo sentir, por diversas feitas, quando nos prelecionou em 1931 a Introdução à Ciência do Direito. Aos dois mestres (professôres Gama Cerqueira e João Arruda) prestamos a homenagem de nossa gratidão aqui. E' expressão incolor e, contudo, bem intencionada, que aqui deixamos.

16. Oxalá, portanto, o que aqui pomos escrito dê os frutos que dêle esperamos, frutos que, como aqui fazemos manifesto, se prenderão à passagem daqueles dois professôres por esta Casa, que, de-menino, aprendemos a venerar. 